\title{
Delitschia gigaspora var. pescanii: a new variety of coprophilous fungus from Brazil
}

\section{Calaça FJS ${ }^{1}$ Delpont $M^{2}$ and Xavier-Santos $S^{1,3}$}

\author{
${ }^{1}$ Laboratório de Biodiversidade do Cerrado - LABBIC, Universidade Estadual de Goiás, Unidade Universitária de \\ Ciências Exatas e Tecnológicas - UEG/UnUCET. BR 153, N³105 CEP 75132-400, Caixa Postal 459, Fazenda \\ Barreiro do Meio-Campus Henrique Santillo-Anápolis, Goiás, Brazil. \\ ${ }^{2}$ Fougas, F-09420 Rimont, France. \\ ${ }^{3}$ Programa de Pós-Graduação em Recursos Naturais do Cerrado (www.prp.ueg.br/renac).
}

Calaça FJS, Delpont M, Xavier-Santos S 2015 - Delitschia gigaspora var. pescanii: a new variety of coprophilous fungus from Brazil. Mycosphere 6(1), 122-126, Doi 10.5943/mycosphere/6/1/12

\begin{abstract}
This study presents a new variety of Delitschia gigaspora, called pescanii, that was obtained in moist chamber cultures of cow dung collected in the Parque Estadual da Serra de Caldas Novas (PESCAN), a conservation unit of the Cerrado bioma (Brazilian Savanna) in the State of Goiás, Brazil. The study also brings the first record of the genus Delitschia for Brazil. A taxonomic description, illustrations, and a dichotomous key for the known varieties of the species are provided.
\end{abstract}

Key words - Ascomycota - Brazilian Savanna - Delitschiaceae - dung fungi

\section{Introduction}

Herbivore dung is an excellent substrate for an ample variety of species of coprophilous fungi (Lundqvist 1972, Bell 1983, 2005, Richardson 2001). The genus Delitschia, proposed by Auerswald in 1866, is characterized by fimicolous species, with pseudothecia immersed to partially immersed in the substrate, bitunicate and non-amyloid asci and dark brown bicellular ascospores, that connected by a septum with germ slit and surrounded by a gelatinous sheath (Luck-Allen \& Cain 1975, Doveri 2004, Bell 2005). Coprophilous species are mainly found in herbivore dung, preferably in bovine dung. According to Doveri (2011), representatives of that genus greatly prefer bovine dung as substrate. Such preference shows that the genus Delitschia is a very demanding genus as for the substrate where it occurs (Lundqvist 1972). With regard to the substrate, the species of coprophilous fungi were subdivided into less demanding fungi, that are able to occur in more than one type of dung, as in dung of monogastric animals in general, such as horse, rabbit, and more demanding, which grow only in a specific type of substrate, restricting themselves to one or a few dung types.

The species D. gigaspora, described by Cain (1934), is characterized by large fusiform spores $(82-88 \times 22-25 \mu \mathrm{m})$, with constricted septum and cells that are susceptible to separation. Two varieties were known so far, namely $D$. gigaspora var. gigaspora Cain (1934) and $D$. gigaspora var. ceciliae (Doveri 2004). The ceciliae variety is considered of rare occurrence, having been found on horse dung in Italy. In Brazil, the genus had never been recorded. This study brings the first record of the genus Delitschia for Brazil and propose a new variety of the species D. gigaspora to the science. 


\section{Materials \& Methods}

Cow (Bos taurus L.) dung was collected in a pasture area of the Parque Estadual da Serra de Caldas Novas (PESCAN), a conservation unit of the Cerrado bioma (Brazilian Savanna), located at $17^{\circ} 43^{\prime}$ and $17^{\circ} 53^{\prime} \mathrm{S}$ and $42^{\circ} 39^{\prime}$ and $42^{\circ} 46^{\prime} \mathrm{W}$, between the municipalities of Caldas Novas and Rio Quente, in the State of Goiás, Brazil (Figure 1). The collected material was incubated in moist chamber, in accordance with the methodology proposed by Lundqvist (1972), Bell (1983) and Doveri (2004).

Found pseudothecia were examined and photographed under stereo and optical microscope, via preparation of histological slides with a drop of sterilized water and stained with lactophenol cotton blue, when necessary, to highlight hardly visible structures and to provide measuring of the microstructures, by following the methodology of Bell (1983). The holotype, preserved in wet way (alcohol 70\%) as well as in permanent slides, were deposited in the Herbarium of the Universidade Estadual de Goiás (HUEG), with registration number HUEG 9204.

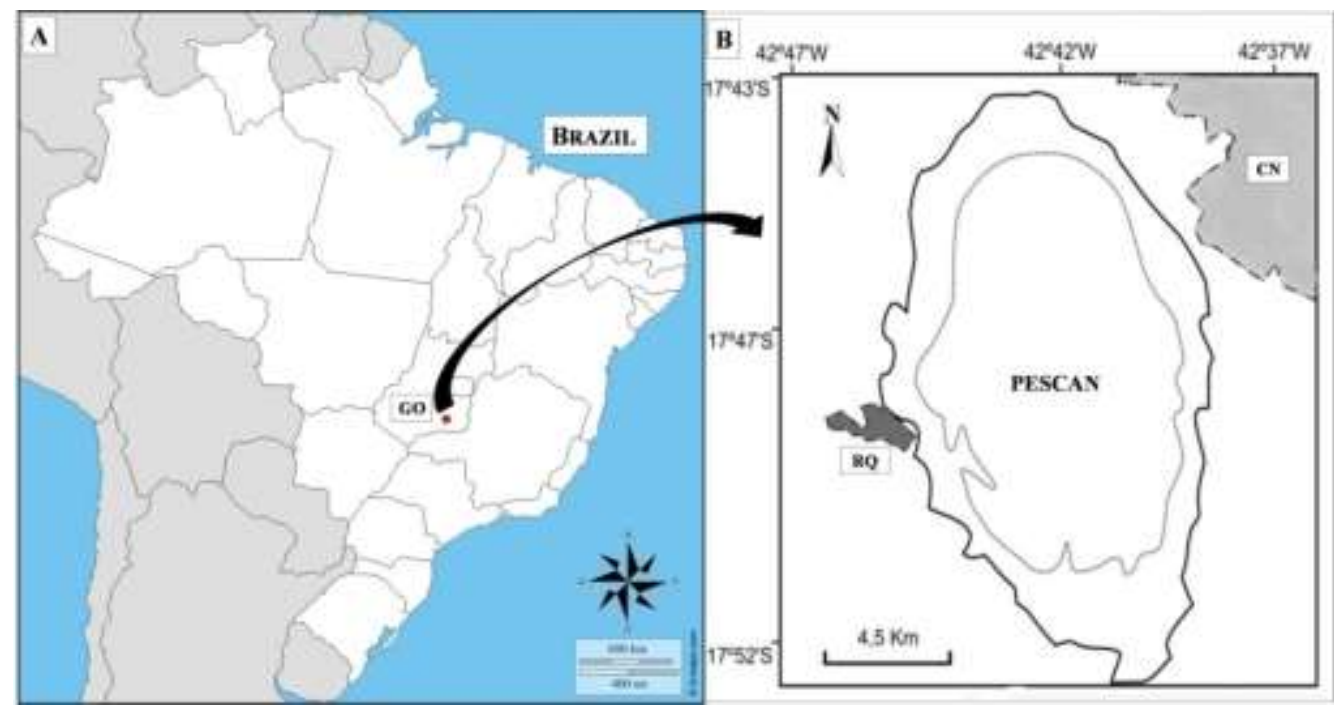

Fig. 1 - Localization of the Parque Estadual da Serra de Caldas Novas (PESCAN). A: The red dot shows the localization of PESCAN in Brazil and in the State of Goiás (GO). B: Localization of the park between the cities of Rio Quente (RQ) and Caldas Novas (CN). Maps modified from www.dmaps.com and Oliveira (2009).

\section{Results \& Discussion}

\section{Taxonomy}

Delitschia gigaspora var. pescanii F.J.S Calaça, S. Xavier-Santos \& M. Delpont, n. var. (Figs. 2 and 3).

MycoBank: 809411

Etymology: From Latin, pescanii, by reference to the variety's collecting place, the Parque Estadual da Serra de Caldas Novas (PESCAN).

Pseudothecia glabrous, with dark walls, partially immersed in the substrate, 500-1000 $\times$ 500-550 $\mu \mathrm{m}$. Asci eight-spored, bitunicate, club to cylindrical, with slightly sharp apex, 500-600 $\times$ $40-50 \mu \mathrm{m}$, with peridium composed of two layers (endoperidium and exoperidium) formed of pseudoparenchymatous tissue, the exoperidium formed of epidermoid cells, 5-10 × 10-20 $\mu \mathrm{m}$, pale to slightly brown color. Ascospores elliptical, 80-85(-87) $\times 25-30(-35) \mu \mathrm{m}$, obliquely uniseriate, with slightly conical to oblique apex; spetate with transverse and unconstricted septum. Ascospore cells not separable at maturity, each one having a de Bary bubble and a germ slit oblique in relation to the cell axis, olive-greenish brown, at maturity, surrounded with a clear gelatinous sheath. Pseudoparaphyses long (usually exceeding the length of asci) and filiform. 
Distribution - known only from the type locality.

Material examined - Brazil, Goiás State, Caldas Novas, Parque Estadual da Serra de Caldas Novas, 18/XII/2013, obtained from cow (Bos taurus L.) dung culture in moist chamber, 29 January 2014, Calaça \& Xavier-Santos FJSC31 (Holotypus HUEG 9204).

Notes - Pseudothecia of D. gigaspora var. pescanii (Figs. 2 and 3) emerged at the end of the first week of incubation, remaining for three consecutive days in the culture, no new emergence being seen after that period.

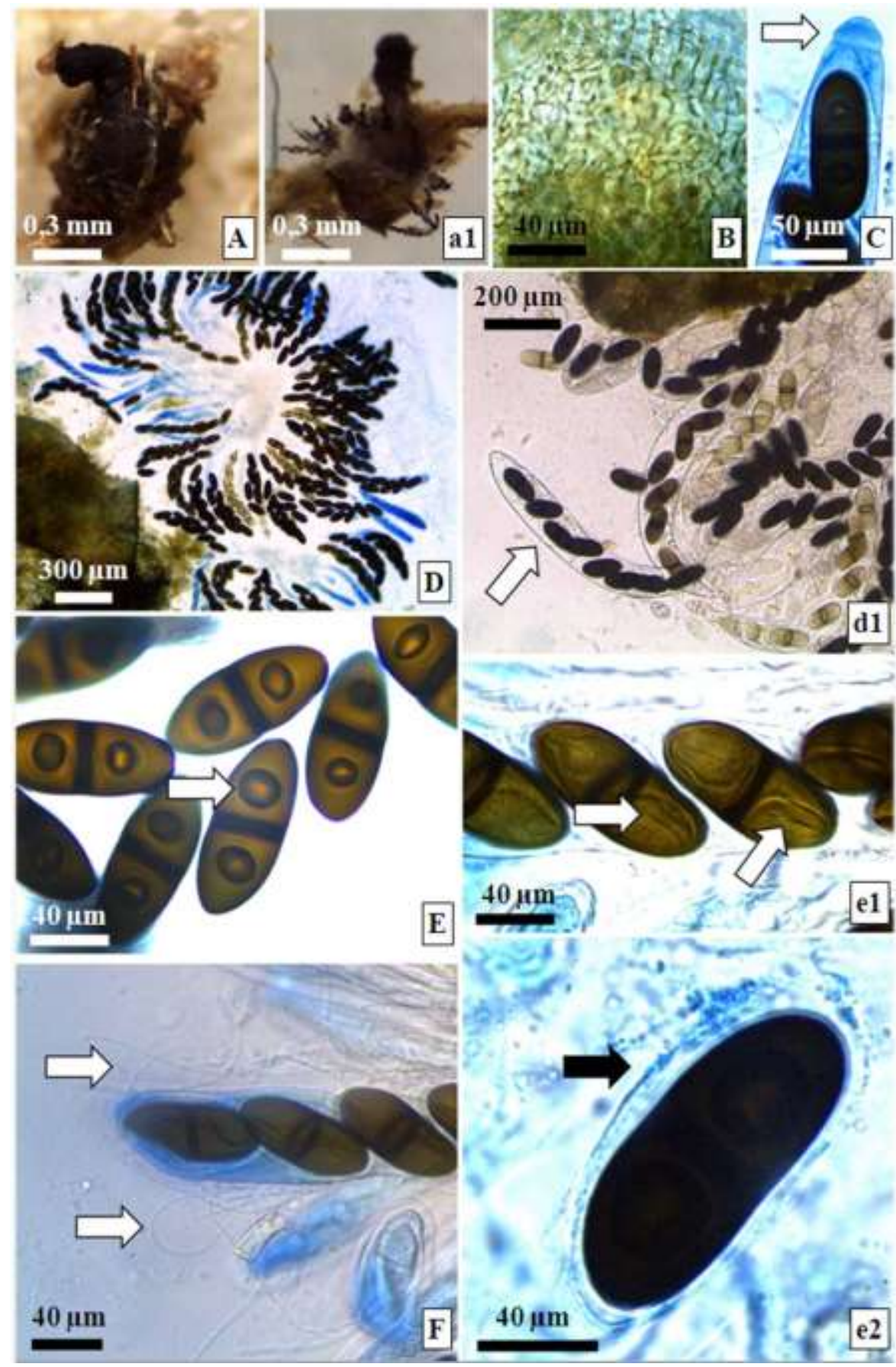

Fig. 2 - Delitschia gigaspora var. pescanii. A-a1: Pseudothecium under stereo microscope. B: Neck peridium (exoperidium) under optical microscope, highlighting the epidermoid texture. C: Detail of the ascus apex (arrow), stained with cotton blue. D-d1: Format of the asci and the organization of the ascospores (arrow). E: Detail of the ascospores, highlighting the de Bary bubbles (arrow). e1: Germ slit in mature ascospores (arrows). e2: Detail of the gelatinous sheath surrounding a mature ascospore (arrow). F: Pseudoparaphyses (arrows). 


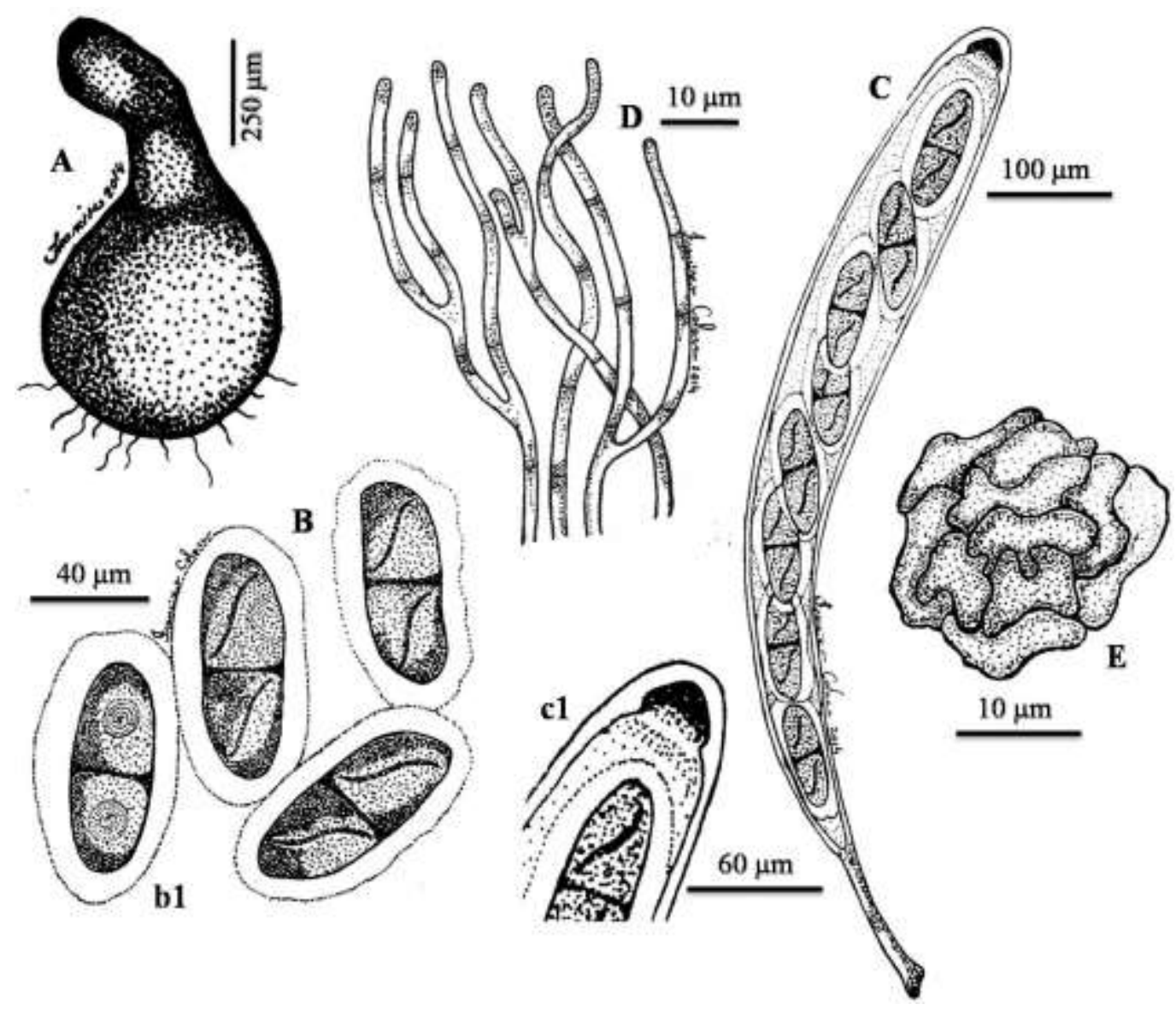

Fig. 3 -Delitschia gigaspora var. pescanii. A: Pseudothecium. B: Mature ascospores, with germ slit. b1: Immature ascospore, with de Bary bubbles. C: Mature ascus. c1: Detail of the ascus apex. D: Pseudoparaphyses. E: Exoperidium cells.

\section{Key to the varieties of Delitschia gigaspora}

1. Pseudothecium glabrous. Ascospores elliptical, 80-85 $\times 25-30 \mu \mathrm{m}$, uniseriate, with unconstricted transverse septum, apex slightly conical to oblique, germ slit oblique in relation to the vertical axis of the ascospores.....................Delitschia gigaspora var. pescanii (Fig. 2 and 3).

1.1 Pseudothecium tomentose. Ascospores different of that described

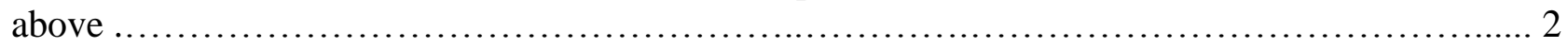

2. Ascospores subfusiform, biseriate, 70-80 × 23-26 $\mu \mathrm{m}$, with unconstricted transverse septum, apex acute to conical, germ slit longitudinal, usually runs for the full length of spore. Delitschia gigaspora var. ceciliae (description in Doveri 2004).

2.1 Ascospores subfusiform, uniseriate to biseriate, 74-95 $\times 20-25 \mu \mathrm{m}$, with constricted transverse septum, apex conical, germ slit longitudinal, running for the full length of spore. ..Delitschia gigaspora var. gigaspora (description in Doveri 2004).

The variety pescanii differs of ceciliae and gigaspora mainly in relation to the pseudothecia, which are glabrous, contrasting with the tomentose pseudothecia of the other varieties, and in relation to the shape of the spores, which are elliptical (with aspect robust) contrasting with the spores subfusiforms of the other varieties (Doveri 2004). Comparison of the varieties are presented in Table 1. Just as in the gigaspora variety, the spores of the pescanii variety do not tend to separation, given that the transverse septum between the ascospore sister cells is less deep than in D. gigaspora var. ceciliae, whose ascospore sister cells can break up (Doveri 2004). 
Table 1 Main differences among the three varieties of Delitschia gigaspora

\begin{tabular}{|c|c|c|c|c|}
\hline Variety & Pseudothecia & Spore & Asci & Substrate \\
\hline D. g. var. gigaspora & $\begin{array}{l}\text { Presence of } \\
\text { tomentum }\end{array}$ & $\begin{array}{c}\text { Long, narrow and } \\
\text { subfusiform, apex conical, } \\
\text { germ slit longitudinal }\end{array}$ & $\begin{array}{l}\text { With uniseriate } \\
\text { or biseriate } \\
\text { ascospores }\end{array}$ & $\begin{array}{l}\text { Usually on leporid } \\
\text { dung }\end{array}$ \\
\hline D. g. var. ceciliae & $\begin{array}{l}\text { Presence of } \\
\text { tomentum }\end{array}$ & $\begin{array}{l}\text { Long, subfusiform, apex } \\
\text { acute to conical, germ slit } \\
\text { longitudinal }\end{array}$ & $\begin{array}{l}\text { With biseriate } \\
\text { ascospores }\end{array}$ & On horse dung \\
\hline D. $g$. var. pescanii & $\begin{array}{l}\text { Absence of } \\
\text { tomentum }\end{array}$ & $\begin{array}{l}\text { Large in comparison to the } \\
\text { total length of the spores, } \\
\text { elliptical, apex slightly } \\
\text { conical to oblique, germ } \\
\text { slit oblique }\end{array}$ & $\begin{array}{l}\text { With uniseriate } \\
\text { ascospores }\end{array}$ & On cattle (cow) dung \\
\hline
\end{tabular}

\section{Acknowledgements}

The authors would like to express their thanks to Dr. Francesco Doveri, Peter Püwert and Peter Welt for their valuable commentaries, to Gabriele Cacialli and Joop Van Der Lee for the granted bibliography, to the administration of the Parque Estadual da Serra de Caldas Novas for the logistic support in the collection of the material, to the Universidade Estadual de Goiás and the PróReitoria de Pesquisa e Pós-graduação (PrP) for the support in the translation of the manuscript and to FAPEG for its financial support (Process nr.201210267001098).

\section{References}

Bell A 1983 - Dung Fung: an illustrated guide to coprophilous fungi in New Zealand. Wellington, Victoria University Press. 88 p.

Bell A 2005 - An illustrated guide to the coprophilous Ascomycetes of Australia.CBS Biodiversity Series No. 3. $172 \mathrm{p}$.

Cain RF 1934 - Studies of Coprophilous Sphaeriales in Ontario. Toronto, The University of Toronto Press. Biological Series, 38. 127 p.

Doveri F 2004 - Fungi Fimicoli Italici: A guide to the recognition of Basidiomycetes and Ascomycetes living on faecal material. Bresadola, Itália, Scientific Committee of the Bresadola Mycological Association (A.M.B.). 1104 p.

Doveri F 2011 - Additions to "Fungi Fimicoli Italici": An update on the occurrence of coprophilous Basidiomycetes and Ascomycetes in Italy with new records and descriptions. Mycosphere 2, 331-427.

Luck-Allen ER, Cain RF 1975 - Additions to the genus Delitschia. Canadian Journal of Botany 53, $1827-1887$.

Lundqvist N 1972 - Nordic Sordariaceae s. lat. Acta Universitatis Upsaliensis, Symbolae Botanicae Upsalienses 20, 439 p.

Oliveira DE 2009 - Estrutura espacial da assembleia de cupins (Isoptera) em cerrado sensu stricto do Parque Estadual da Serra de Caldas Novas, Goiás. Universidade Federal de Goiás. Master Thesis, $61 \mathrm{pp}$.

Richardson MJ 2001 - Diversity and occurrence of coprophilous fungi. Mycological Research $105,387-402$.

www.indexfungorum.org -2015.

www.mycobank.org - 2015 . 